\title{
Segmental Speech Timing at the Phoneme and Syllable Levels in English and Afrikaans Speaking White South African Children
}

\author{
Carol L Oosthuizen, Ph D (Cape Town) \\ Department of Otorhinolaryngology \\ University of Stellenbosch
}

\begin{abstract}
Two aspects of segmental timing were acoustically measured in the speech production of 30 English and 30 Afrikaans speaking white South African children. These were VOT and medial stop closure duration in VCV nonsense syllables. In addition, medial vowel duration in CVC nonsensesyllables was measured in English speakers. Comparisons were made between:younger (mean age 4.25 years) and older (mean age 6.5 years) subjects in each language group.

Graphical statistical methods revealed certain trends in the datá. English speakers employed short-and long-lag VOT for voiced and voiceless stops while Afrikaans speakers used two short-lag categories. Contextually determined right-to-left timing effects were identified which were in agreement with the literature, with different rates of acquisition of medial stop closure duration rules being observed between the language groups.
\end{abstract}

\section{OPSOMMING}

Twee aspekte van segmentele tydreëling in die spraakproduksie van 30 Engels-en 30 Afrikaanssprekende blanke Suid-Afrikaanse kinders is akoesties gemeet. Dit was stemaanvangstyd en tydsduur van mediale plosiewe sluiting in VKV onsinlettergrepe. Tydsduur van mediale vokale in KVK onsinlettergrepe is ook in Engelssprekendes gemeet. Vergelykings is ook gemaak tussen jonger (gemiddelde ouderdom 4.25 jaar) en ouer (gemiddelde ouderdom 6.5 jaar) proefpersone in elke taalgroep.

Dit is bevind dat Engelssprekendes gebruik maak van kort en lang vertraging in stemaanvangstyd vir stemhebbende en stemlose plosiewe, terwyl Afrikaanssprekendes twee kort vertragingskategorieë. gebruik. Regs-tot-links konteksgebonde neigings wat in segmentele tydreëling geidentifiseer is, het met die literatuu ooreengestem terwyl verskillende tempo's van verwerwing van reëls vir tydsduur van mediale plosiewe tussen die taalgroepe waargeneem is.

Temporal aspects of speech production have been highlighted by Kent (1976) as possibly "... the most critical factor in skilled motor performance." ( $\mathrm{p} 438$.) The development of speech timiAg is thought to reflect neuromaturation of the speech mechanism and has important implications for many branches of the study of communication dișorders. Kent points out that phonetic judgments are only gross indicators of motor speech development and that more sensitive parameters of motor skills, such as the acquisition of segmental timing rules, continue to develop after children have acquired the basic phonological system.

Some developmental patterns in segmental timing have been demonstrated (inter alia, by Kewley-Port \& Preston, 1974; DiSimoni, 1974 a,b,c; Tingley \& Allen, 1975; Menyuk \& Klatt, 1975; Gilbert, 1976; Gilbert \& Johnson, 1978; Smith, 1978; Macken \& Barton, 1979; Flege, McCutcheon \& Smith, 1987) but the still inadequate body of research on the subject precludes a comprehensive description. Development in the various levels of speech timing has not been fully investigated. Cooper (1977) identified three levels on which children learn control of speech timing:

1. The phonetic-phonemic level, such as voice onset time (VOT), i.e the time taken from the release of a stop plosive closure to the onset of voicing for the post-consonantal vowel.
2. The syllable level, comprising rules for the timing of sounds within syllables. This can be illustrated by a temporal compensation rule which states that a longerthan-average vowel must be followed by a shorter-thanaverage consonant.

3. The sentence level. Both children and adults seem to preplan the timing of segments within utterances, e.g. the longer the utterances, the shorter the individual segments.

A fourth level of speech timing may be added (Dalton \& Hardcastle, 1977), viz.:

4. The prosodic level, i.e. transition smoothness between intonation units.

It is not yet known whether measures of timing variables in very young children would predict later motor speech performance. The intriguing question of whether or not there is a relationship between speech timing development and speech disorders has only been addressed in a preliminary, way with regard to articulation disorders (Weismer \& Elbert, 1982), phonological disorders (Catts \& Jensen, 1983; Smit \& Bernthall, 1983), cleft palate (Forner, 1983), hearing impairment (Stark, 1972), delayed language development (Bord \& Wilson, 1980) and stuttering (inter alia, DiSimoni, 1974c; 
Starkweather et al. 1976; Starkweather « Myers, 1979; Oosthuizen, 1986; Adams, 1987; McKnight \& Cullinan, 1987).

A description of normal development should be the precursor to the study of timing problems in speech disorders. No normative study of speech timing in South African children has yet been published and this report represents a limited attempt to explore a vast subject. Most white South African children speak English or Afrikaans, which have been the two official languages since 1925. Owing to historical and geographical influences, South African English is a dialect which differs from forms of English found in other countries (Lanham, 1967). Afrikaans is a Germanic language which was derived from Dutch. It cannot be assumed that the findings of studies of speech timing using speakers of other English dialects or Germanic languages can automatically be applied to speakers of South African English or Afrikaans. Separate investigations are merited which might eventually yield valuable insights into the relationships between the development of speech timing, dialect and language.

The three aspects of expressive speech timing which form the topic of this report fall within the phonetic-phonemic and syllable levels. They are syllable-initial VOT, syllable-medial stop closure duration and syllable-medial vowel duration. These segmental timing elements were studied in the speech of English and Afrikaans speaking white South African children and formed part of a larger study directed toward the speech of stutterers (Oosthuizen, 1986). They will be discussed as three separate experimental procedures carried out on the same subjects, experiment three using English speaking subjects only.

\section{EXPERIMENT ONE.}

\section{Aim}

The aim of experiment one was to identify normal trends for VOT production of syllable-initial stop plosives in the experimental groups. VOT is an important dimension of segmental timing, since it is a valid measure to differentiate phonemic voicing categories in many languages.

Most studies of VOT production in children have employed very small subject samples, nevertheless some developmental trends have emerged. Kewly-Port and Preston (1974), studying American English children (n3), found that, initially, short-lag VOTs predominated with a gradual increase in longlag VOTs. Those findings were confirmed by Macken and Barton (1979) who noted that their 4 subjects had reached adult contrast values by 2.4 years. However, a small sample of Canadian English children failed to demonstrate adult $/ \mathbf{t} /$ values by three years (Gilbert 1976). In reviewing the literature, Kent (1976) concluded that VOT attains adult stability around eight years of age.

Method

Subjects

30 English and 30 Afrikaans speaking white South African children from monolingual homes in the Cape Peninsula were divided into younger and older age groups (see table 1). The subjects had no known medical or neurological disorders, nor any history of communication problems and had passed hearing screening tests.
Table 1: Subject groupings with mean ages in years and months

\begin{tabular}{|l|c|c|}
\hline SUBGROUP (N-15) & MEAN AGE & AGE RANGE \\
\hline 1. Older English speakers & $6,10 \mathrm{yrs}$ & 6,5 to 7,6 \\
2. Older Afrikaans speakers & $6,9 \mathrm{yrs}$ & 6,4 to 7,10 \\
3. Younger English speakers & $4,4 \mathrm{yrs}$ & 4,0 to 5,0 \\
4. Younger Afrikaans speakers & $4,1 \mathrm{yrs}$ & 3,1 to 4,8 \\
\hline
\end{tabular}

Procedures for data collection

Four productions of each of the following $\mathrm{CVC}$ nonsense syllables were elicited from each subject and recorded on audio tape:

/paf/ /baf/ /taf/ /daf/

The subjects'were tested individually in a quiet environment. The syllables were used in a story context by an adult native speaker of each language, following a procedure described by Hawkins (1973), after which deferred imitations were elicited from the children.

\section{Data Analysis}

Storage oscilloscopic displays of the first three clear, isolated productions of each of the syllables for each subject were obtained using an electronic memory (Biomation Model 1015) and Tektronix $5103 \mathrm{~N}$ oscilloscope. Judgment of speech segmental boundaries in the display followed the guidelines laid down by Shoup and Pfeifer (1976) and segments were measured in milliseconds. The VOT of each production was classified as falling in to the short-, long-lag, or voicing lead categories. In their seminal study of adult native speakers of eleven languages, Lisker and Abramson (1964) identified three categories of VOT values:

Prevoicing (voicing lead): -125 to zero msecs Short-lag: zero to $/ 25 \mathrm{msecs}$

Long-lag: $/ .60$ to $/ 100$

It is now generally accepted that a VOT boundary of approximately / 35 msecs separates the short- and long-lag categories in English (Cooper, 1977), a figure which corresponds with the perceptual boundary.

\section{Statistical Treatment}

Owing to the small number of subjects (15) in each subgroup, and given the exploratory nature of the study, graphical statistical methods were applied. Multiple box plots were used to display the central tendency and spread of the mean, the range, maximum and minimum scores for each production of each syllable.

\section{Results and discussion}

Figure 1 shows summary box plots illustrating the relative VOT values for the /paf/-/baf/ cognate pair in the four experimental groups. Comment on the distribution refers to the interquartile distance, chosen as a measure of spread, and the median, chosen as a central value. These parameters were 
regarded as preferable to the standard deviation or arithmetic mean, since many of the distributions were asymmetrical; they have the additional advantage of being little affected by outlying scores. Outlying scores are represented on the distribution by asterisks in a vertical column. Results for the /taf/-/daf/ cognate pair (not shown) were comparable and are included in the comments.

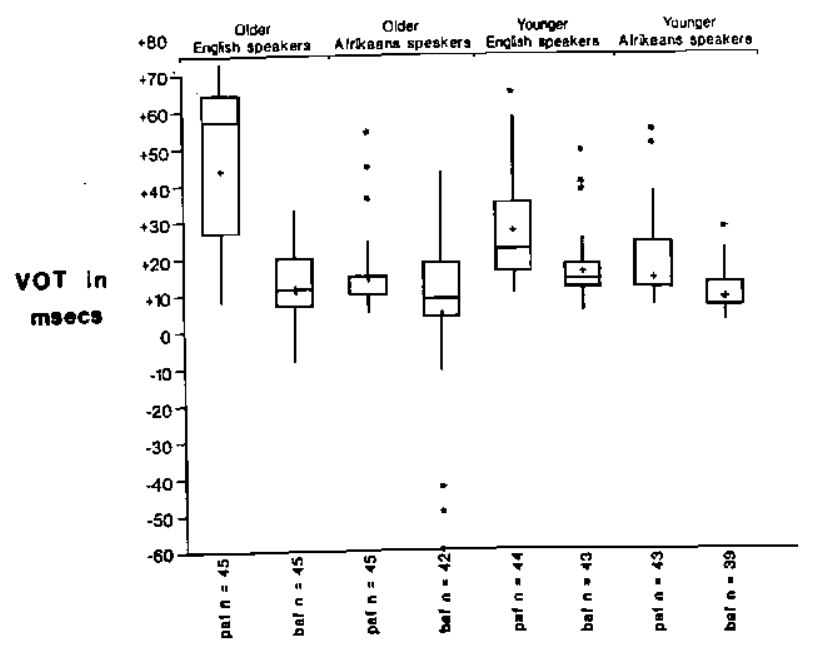

Figure 1 Summary box plots showing VOT values for the /paf/-/baf/ cognate pair in the four groups of subjects. A few extreme prevoicing scores have been omitted in older Afrikaans speakers.

While there was a degree of overlap between VOTs for voiced and voiceless cognate pairs, older English speakers made clearer distinctions between them than did their Afrikaans peers. South African English appears to be a two category dialect employing short- and long-lag VOT contrasts for voiced and voiceless stops respectively. Afrikaans speakers appeared to use two sets of unaspirated stops for 'voiced' and 'voiceless' sounds all of which fell into the short-lag category, a finding which provides documentary evidence of a feature which is familiar to Afrikaans phoneticians (de Villiers, 1967).

Older English speakers showed a greater trend toward longlag VOTs on voiceless stops/than did younger ones. This is in agreement with the reported developmental findings, that children have to learn to lengthen VOT. Afrikaans speakers did not show VOT lengthening for voiceless stops with age, since they did not employ the long-lag category.

Analysis of multiple box plots of the range (not shown) indicated increased variability of VOT on voiceless stops with age in the case of English speakers. This was attributed to the inherent scope of the long-lag category, which permits'a wide variety of acceptable scores. Most Afrikaans speakers showed decreased variability of production with age; which agrees with previous findings (Eguchi and Hirsch, 1969; DiSimoni, 1974a, 1974b; Tingley and Allen, 1975; Zlatin and Koenigsknecht, 1976). However, some individuals showed increased variability for voiced stops owing to the development of voicing lead as a stylistic variant.

In the case of the South African English children, the means for long-lag VOT were considerably smaller than those reported in the literature for American English children, yet they fell in to the adult long-lag range identified by Abramson and Lis- ker (1974). This relative reduction of VOT for voiceless syllable initial stop plosives reflects the local dialect, since the older English speakers' scores were comparable to adult data obtained in an unpublished pilot study. Speculation regarding the various influences on the local dialect which could affect segmental timing would be premature as ideas in this regard are currently under review (Lass, personal communication 1986).

\section{EXPERIMENT TWO}

DiSimoni (1974a, 1974b), studying American English children, found that the influence of phonetic context on segmental durations appeared between three and six years of age and approached, but did not yet reach adult levels, by nine years. In VCV syllables, the stop closure durations of both voiced and voiceless stops were found to be greater in $/ i /$ than in $/ a /$ environments. The present experiment set out to determine whether similar trends characterized the speech of South African children.

\section{Procedures for data collection for experiments 2 and 3.}

Two randomized word lists, each containing eight nonsense syllables and yielding three nonconsecutive productions of each syllable by each subject were audio recorded. In experiment 2 these were VCV syllables:

lapa/ /aba/ /ata/ /ada/

/ipi/ /ibi/ /iti/ /idi/

The task was one of imitation of an adult speaker, recorded in the case of older subjects and live voice presentation for younger subjects, the syllables being preceded by a carrier phrase. The preconsonantal vowels were stressed in experiment 2 .

\section{Data Analysis}

Two measures were taken from each production of each syllable, viz. whole syllable duration and the closure phase of the medial stop plosive.

\section{Results and discussion}

Figures 2 - 5 contain summary multiple box plots illustrating the central tendency and spread of stop closure duration scores for the experimental syllables in the four groups.

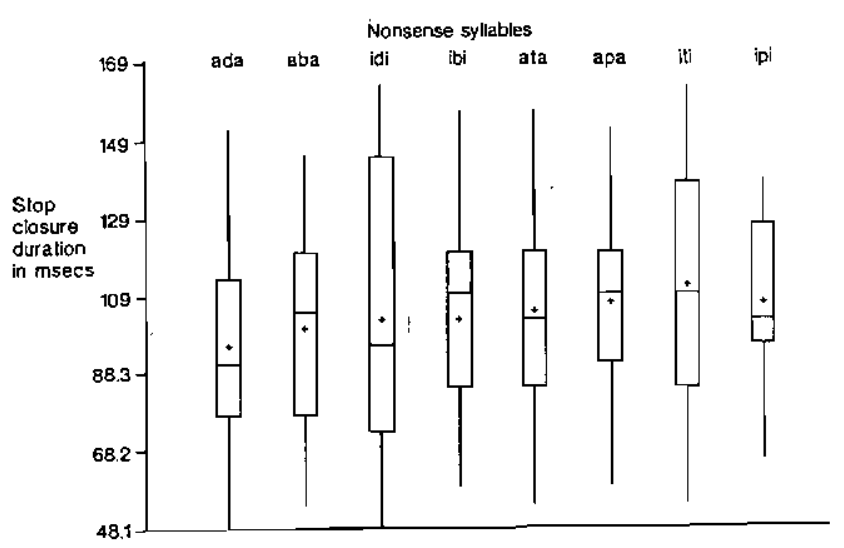

Figure 2 Summary box plots showing the central tendency and spread of stop closure durations in VCV syllables in older English speakers. 


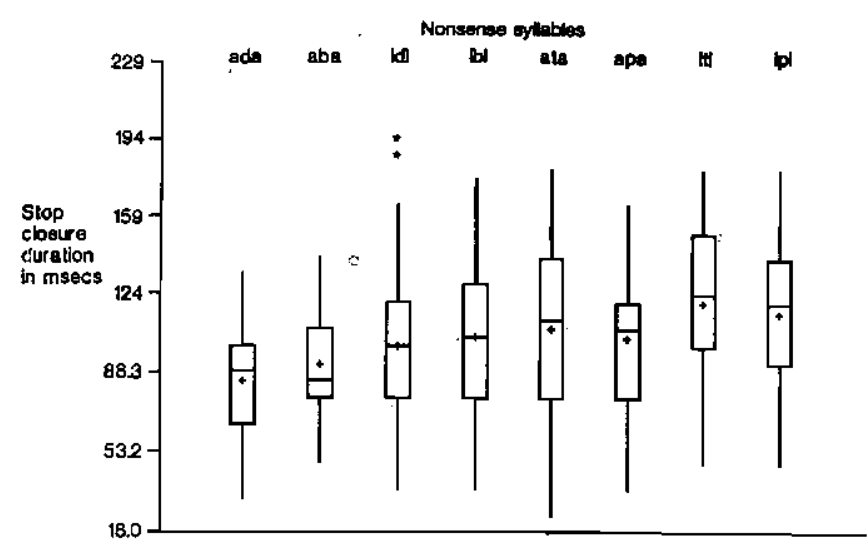

Figure 3 Summary box plots showing the central tendency and spread of stop closure durations in the VCV syllables in older Afrikans speakers.

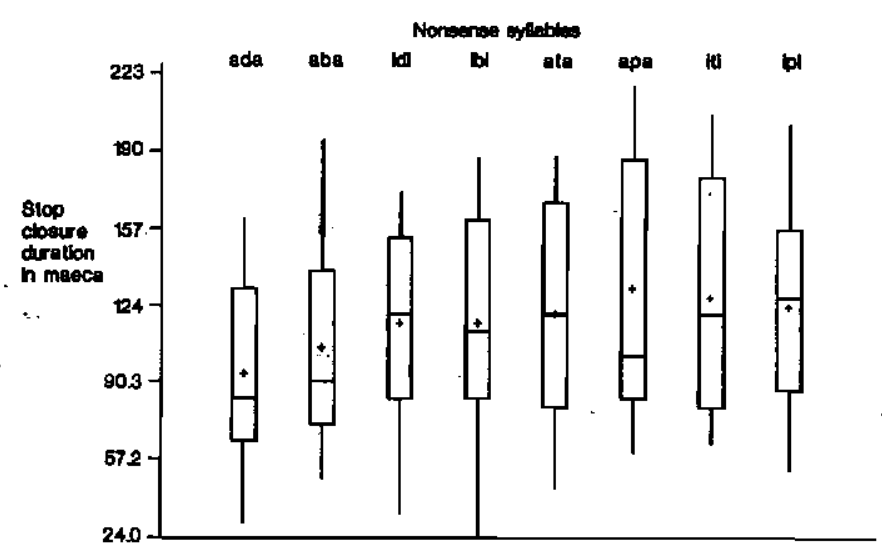

Figure 4 Summary box plots showing the central tendency and spread of stop closure durations in VCV nonsense syllables in younger English speakers.

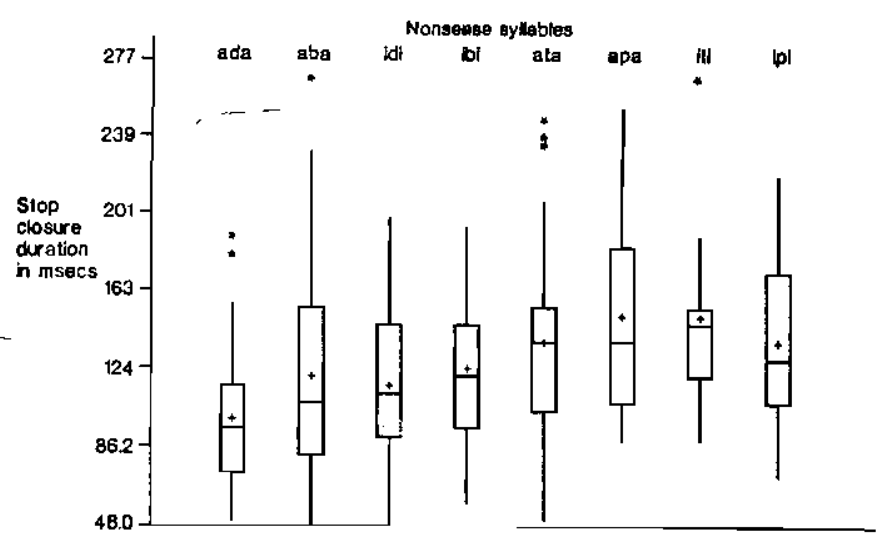

Figure 5 Summary box plots showing the central tendency and spread of stop closure durations in VCV syllables in younger Afrikaans speakers.

No differences emerged between the older language groups with respect to stop closure duration trends. Both groups showed longer medial stop closure durations for voiceless compared with voiced stops. Stop closure durations were also longer in $/ \mathrm{i} /$ than in $/ \mathrm{a} /$ environments. These findings are con- sistent with the results of acoustic studies (Schwartz, 1969; DiSimoni, 1974a; Suen and Beddoes, 1974; Smith, 1978) as well as a physiological study by Butcher and Weiher (1976). Schwartz (1969) attributed the shorter stop closure duration prior to /a/ to coarticulation, the earlier consonant release compensating for the greater distance to be covered in order to reach the low vowel position compared with the high one.

In contrast to Canadian English adults (Suen \& Beddoes, 1974) the South African children showed greater mean' stop closure duration differences between cognate pairs for alveolar sounds than for bilabials. Perhaps this place-of-articulation effect results from relatively poor motor capabilities of the tongue tip in children.

The younger South African English speakers had a mean closure duration difference between voiced and voiceless stops of 16,7 msecs, which is far below the values reported by Smith (1978) for American English children of comparable ages. These discrepancies probably reflect dialectal differences, although methodological factors cannot be discounted.

There appeared to be a developmental trend in the direction of lengthening of medial stop closure duration of voiceless stops. This voicing distinction seemed to be acquired earlier in both vowel environments in Afrikaans speakers compared with English speakers. A second age-related trend, which was also interpreted as reflecting a developmental pattern, was toward lengthening of medial stop closure duration in the high vowel environment.

Variability of timing production was greater amongst younger speakers compared with older ones, confirming the reported trend in the literature. Whole syllable durations did not decrease with age, however. Another unexpected finding was that of greater whole syllable durations in English than in Afrikaans speakers. This cannot simply be attributed to longer VOTs in the English group. VOT lengthens with age, yet whole syllable durations were longer in younger than in older speakers. Since stop closure durations per se, which included transitions, did not differ between the language groups, it seems that the English speakers may have been using longer vowels than did their Afrikaans counterparts. The final vowel is generally thought to exert most influence on medial stop closure duration (Anderson, 1975), but there is conflicting evidence regarding the influence of the preceding vowel (Schwartz, 1969; Butcher \& Weiher, 1976). Since both vowels were the same in each syllable, it is not possible to determine which was affecting medial stop closure durations.

The lack of consistent age related trends for whole syllable duration is in agreement with Kubaska and Keating (1981) who observed that, provided that the positions of words in utterances were controlled, and once children had reached the two-word utterance stage of development, word durations did not change much over time in American English children (n3).

\section{EXPERIMENT THREE}

This experiment was performed on English speakers only, since final voiced stops and fricatives do not normally occur in Afrikaans (Combrink \& de Stadler, 1987).

Vowels which precede voiced stops have been shown to be approximately 100 msecs longer than those preceding final 
voiceless stops in adult speech (House \& Fairbanks, 1953; Peterson \& Lehiste, 1960). Naeser (1970), Smith (1978) and Krause (1982) have demonstrated similar trends in 2-3 year old American English children. The phenomenon has also been identified in older children by DiSimoni (1974b) who indicated that development was in the direction of vowel lengthening for voiced consonants rather than shortening for voiceless consonants.

This experiment was aimed at determining the trends characterizing the English speaking subgroups in terms of medial vowel duration relative to the consonant environment in CVC nonsense syllables.

\section{Data Collection and Analysis}

The word lists contained these CVC nonsense syllables:

/pip/ /pap/ /sis/ /sas/

/bib/ /bab/ /ziz/ /zaz/

Measures were taken of vowel and whole syllable durations.

\section{Results and discussion}

Figures 6 and 7 show summary box plots indicating vowel durations for the eight syllables in the two subgroups. Results showed that vowels were longer in sibilant than in stop plosive contexts as well as in voiced compared with voiceless consonant environments.

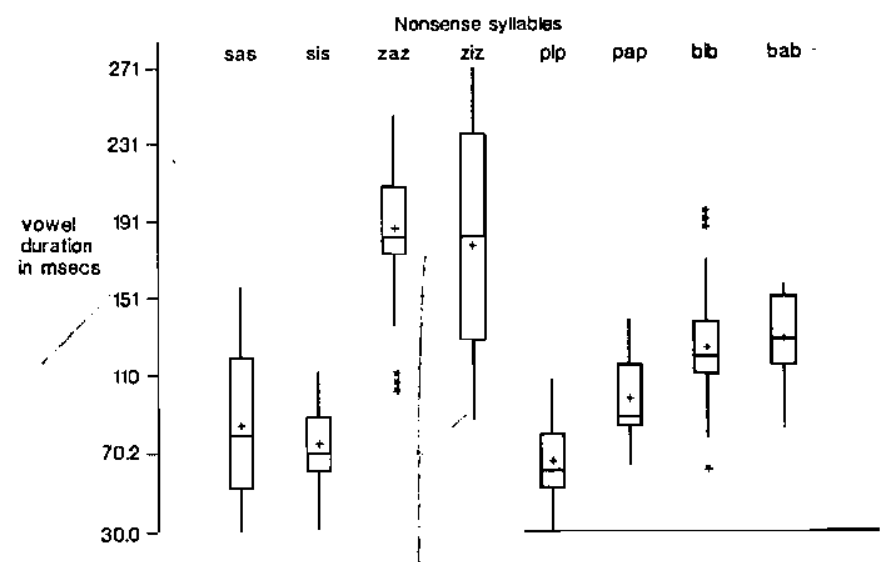

Figure 6 Summary box plots showing the central tendency and spread of vowel durations in CVC syllables in Older English speakers.

Contrary to other reports (reviewed by Kent; 1976), segment durations did not decrease with age. However, an age-related trend was identified in the increasing differential vowel duration relative to both voicing and manner-of-articulation of the voiced consonant context. Decreasing variability of performance with age was found on measures of whole syllable duration.

\section{GENERAL DISCUSSION}

The segmental phonetic level of speech timing, which would include VOT, is considered by Dalton and Hardcastle (1977) to be dependent on aerodynamic coordination. The relatively late development of long-lag VOT in speakers of those languages which use it might be attributed to its greater neuro-

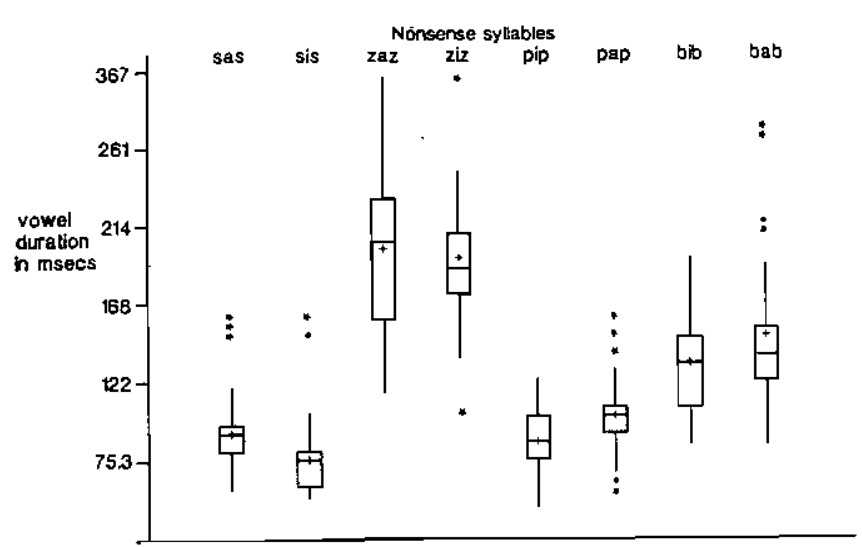

Figure 7 Summary box plots showing the central tendency and spread of vowel durations in CVC syllables in younger English speakers.

physiological complexity, compared with short-lag VOT (Cooper, 1977). However, Lisker (1975) suggested that VOT was influenced by an interaction between biological restraints and phonological rules.

The general decrease in mean segment duration which has been reported as a function of age (Smith, 1978; Kent \& Forner, 1980) and the development of long-lag VOT might largely reflect increasing neuromuscular capabilities. It has been proposed (Suen \& Beddoes, 1974) that the relatively late development of longer stop closure durations for voiceless stops reflects the increased muscular effort required to produce them. This argument is challenged by the cross-language findings in the South African children, the relatively early development of longer closure durations in Afrikaans speakers suggesting that phonological considerations may be important. It seems that certain elements of speech timing are singled out for this kind of development in the age group studied, probably on the basis of their phonological significance.

This issue of the relative contribution of biomechanical and phonologically-programmed influences on segmental speech timing is further complicated by the probable lack of a simple one-to-one relationship between the underlying phonological segmental length specification and the observable phonetic duration. Allen (1973) has suggested that sources of variation would include speech tempo, biological restraints (such as jaw mass) and aerodynamic factors.

\section{CONCLUSION}

In the main, the segmental timing trends identified in the South African subjects agreed with those reported in the literature, i.e.:

1. Increasing VOT for voiceless stops as a function of age in English speakers.

2. Longer medial stop closure durations in VCV syllables when the stop was voiceless and in high vowel environments. A developmental trend toward the acquisition of differential stop closure durations were observed.

3. Longer medial vowel durations in CVC syllables in voiced and voiceless sibilant consonant environments and a developmental trend in this regard in English speakers. 
South African English was identified as a two-category language employing short- and long-lag VOTs for voiced and voiceless stops respectively. Afrikaans speakers appeared to use two short-lag categories with random voicing lead on voiced stops in some subjects.

The fact that there were mixed findings regarding decreasing variability of production as a function of age may be attributed to the relatively small age gap between the older and younger groups of subjects.

Differences between speakers of the two languages with respect to rate and, to a lesser extent, degree of acquisition of anticipatory contextual timing effects highlighted the importance of comparing cross-language data when interpreting research results in this area of study.

The research findings on segmental timing effects in the connected speech of adult speakers (Chrystal \& House, 1988) suggest that due caution should be observed when attempting to generalize from data derived from isolated words or syllables. Such restricted stimuli may bear a close relation only to utterance:initial and prepausal words in connected speech, but this remains to be determined.

\section{REFERENCES}

Abramson, A.S. and Lisker, L. Voice-timing perception in Spanish word-initial stops. J. Phonetics, 5, 1-7, 1974 .

Adams, M.R. Voice onsets and segment durations of normal speakers and beginning stutterers. J. Fluency Dis, 12, 133-139, 1987.

Allen, G.D. Segmental timing control in speech production.J. Phonetics, 1, 219-237, 1973.

Anderson, B.W. Ballistic control of rhythmic articulatory movements in normal speech. N.Y. Acad. of Sciences, 263, 236-243, 1975.

Bord, $Z$. and Wilson, $H$. Acquisition of the voicing contrast by language-delayed and normal-speaking children. J. Speech Hear. Res., 23, 152-161, 1980.

Butcher, A. and Weiher, E. An electropalatographic investigation of coarticulation in VCV sequences. J. Phonetics, 4, 59-74, 1976.

Catts, H.W. and Jensen, P.J. Speech timing of phonologically disordered children: voicing contrast of initial and final stop consonants. J. Speech Hear. Res. 26, 501-510, 1983.

Combrink, J.G.H. and de Stadler, L.G. Afrikaanse Fonologie. Johannesburg: MacMillan, 1987.

Cooper, W.E. The development of speech timing. In S.J. Segalowitz and F.A. Gruber (Eds.) Language Development and Neurological Theory. New York : Academic, 1977.

Crystal, T.H. and House, A.S. Segmental durations in connectedspeech signals: current results. J. Acoust. Soc. Am., 83, 15531573,1988

Dalton, P. and Hardcastle, W.J. Disorders of Fluency. London: Arnold, 1977.

De Villiers, M. Afrikaanse Klankleer. Cape Town : Balkema, 1967.

DiSimoni, F.G. Influence of vowel environment on the duration of consonants in the speech of three-, six-, and nine-year old children. J. Acoust. Soc. Am., 55, 360-361, 1974a.

DiSimoni, F.G. Influence of consonant environment on duration of vowels in the speech of three-, six-, and nine-year old children. $J$. Acoust. Soc. Am, 55, 362-363, 1974b.

DiSimoni, F.G. Preliminary study of certain timing relations in the speech of stutterers. J. Acoust. Soc. Am., 56, 695-696, 1974c.

DiSimoni, F.G. Some preliminary observations on temporal compensation in the speech of children. J. Acoust. Soc. Am., 56, 697699 , 1974d.

Eguchi, S. and Hirsh, I.J. Development of speech sounds in children. - Acta Oto-larymgologica, Suppl. 257, 1969.

Flege,J.E., McCutcheon, M.J. and Smith, S.C. The development of skill in producing word-final English stops. J. Acoust. Soc. Am., 82, 433-447, 1987.

Forner, L.L. Speech segment durations produced by five and six year old speakers with and without cleft palate. Cleft Palate J., 20, 185-198, 1983

Gilbert, J.H.V.A voice onset time analysis of apical stop production in three-year-olds. J. Child Lang., 4, 103-110, 1976.

Gilbert, J.H.V. and Johnson, C.E. Temporal and sequential constraints on six-year-old's phonological productions: some ob- servations on the 'ambliance' phenomenon. J. Child Lang., 5, 101-112, 1978 .

Hawkins, S. Temporal coordination of consonants in the speech of children : preliminary data. J. Phonetics, 1, 181-217, 1973.

House, A.S. and Fairbanks, G. The influence of consonant environment upon the secondary acoustical characteristics of vowels.J. Acoust. Soc. Am., 25, 105-113, 1953.

Kent, R.D. Anatomical and neuromuscular maturation of the speech mechanism : evidence from acoustic studies J. Speech Hear. Res., 19, 421-447, 1976.

Kent, R.D. and Forner, L.L. Speech segment durations in sentence recitations by children and adults. J. Phonetics, 8, 157-168, 1980.

Kewly-Port, D. and Preston, M.S. Early apical stop production : a voice onset time analysis. J. Phonetics, 2, $195-210,1974$.

Krause, S.E. Developmental use of vowel duration as a cue to postvocalic consonant voicing. J. Speech Hear. Res. 25, 388-398, 1982 .

Kubaska, C.A. and Keating, P.A. Word duration in early child speech. $J$. Speech Hear. Res., 24, 615-621, 1981.

Lanham, L.W. The Pronunciation of South African English. Cape Town Balkema, 1967

Lass, R. Personal communication - Department of Linguistics, University of Cape Town, December 1986.

Lisker, L. Is it VOT or a first-formant transition detector? J. Acoust. Soc. Am. 57, 1547-1551, 1975.

Lisker, L. and Abrahamson, A.S. A cross-language study of voicing in initial stops : acoustical measurements. Word, 20, 384-422, 1964.

Mack, M. Voicing-dependent vowel duration in English and French : monolingual and bilingual production.J. Acoust. Soc. Am., 71 $173-178,1982$.

Macken,M.A. and Barton, D. The acquisition of the voicing contrast in English : A study of voice onset time in word-initial stop consonants. J. Child Lang., 7, 41-74, 1979.

McKnight, R. and Cullinan, W. Subgroups of stuttering children: speech and voice reaction times, segmental durations, and naming latencies. J. Fluency Dis., 12, 217-233, 1987.

Menyuk, P. and Klatt, M. Voice onset time in consonant cluster production by children and adults. $J$. Child Lang., 2, 223-231, 1975.

Naeser, M.A. The influence of initial and final consonants on vowel duration in CVC syllables. Technical report No. 130, Wisconsin Research and Development Center for Cognitive Learning, University of Wisconsin, 1970.

Oosthuizen, C.L. A Cross-linguistic study of certain temporal features of speech in stuttering and nonstuttering children. Unpublished Doctoral thesis, University of Cape Town, 1986.

Peterson, G.E. and Lehiste, I. Duration of syllable nuclei in English. $J$. Acoust. Soc. Am., 32, 693-703, 1960.

Schwartz, M. Influence of vowel environment on the duration of $/ \mathrm{s} /$ and $|S|$. J. Acoust. Soc. Am. 46, 480-483, 1969.

Shoup, J.E. and Pfeifer, L.L. Acoustic characteristics of speech sounds. In N.J. Lass (Ed.) Contemporary Issues in Experimental Phonetics. New York : Academic, 1976

Smit, A.B. and Bernthall, J.E. Voicing contrasts and their phonological implications in the speech of articulation-disordered children! J. Speech Hear. Res, 26, 486-500, 1983.

Smith, B.L. Temporal aspects of English speech production : a developmental perspective. J. Phonetics, 6, 37-68, 1978.

Stark, R. Some features of the vocalizations of young deaf children. In J.F. Bosma (Ed.) Third Symposium on Oral Sensation and Perception: The mouth of the Infant Springfield, Ill.: Thomas, 1972.

Starkweather, C.W. and Myers, M. Duration of subsegments within the intervocalic interval in stutterers and nonstutterers. $J$. Fluency Dis., 4, 205-214, 1979.

Starkweather, C.W., Hirschman, P. and Tannenbaum, R.S. Latency of vocalization onset: stutterers versus nonstutterers. J. Speech Hear. Res., 19, 481-492, 1976.

Suen, C.Y. and Beddoes, M.P. The silent interval of stop consonants. Lang. Speech, 17, 126-134, 1974.

Tingley, B.M. and Allen, G.D. Development of speech timing control in children. Child Dev., 46, 186-194, 1975.

Weismer, G. and Elbert, M. Temporal characteristics of the "functionally" misarticulated /s/in 4 - 6-year-old children. J. Speech Hear. Res., 25, 275-287, 1982.

Zimmermann, G.N. and Sapon, S.M. Note on vowel duration seen cross-linguistically. J. Acoust. Soc. Am., 30, 152-153, 1958.

Zlatin, M.A. and Koenigsknecht, R.A. Development of the voicing contrast : a comparison of voice onset time in stop perception and production. J. Speech Hear. Res., 19, 93-111, 1976. 